\title{
The Challenges of the Meat Industry That Impact on the Operations of Kenya Meat Commission
}

\author{
George Murithi Nyamu ${ }^{1}$, James Kathuri Ndwiga ${ }^{2}$ \\ Jomo Kenyatta University of Agriculture and Technology Kenyatta University College-Mombasa
}

\begin{abstract}
Identifying what the customers want and doing a better job of giving it to them, will make all the difference in the company's future. It is also important to understand government policies and regulations in the business industry, its implications to the business, and how to develop strategies necessary to lobby the government to provide the best legal framework. The importance of this is that where those regulations are not aligned to create a conducive environment for trade, the businesses cannot effectively compete. Lastly, finding the right staff is a significant factor in the success of a business. Without exception, the biggest challenge in business is finding the right staff, retaining them, and ensuring they buy into the vision of the business. A small business is almost like a family, and, like many families, they can work well, or they can be dysfunctional. In big companies, the human resource challenge is politics in the workplace, while in small business, its personalities and skill. When you work in a small environment, each team member's personality can have a huge impact on the harmony and productivity of the business.
\end{abstract}

Key words: Competition, Meat industry, Government policy and Compliance to international standards

\section{Introduction}

The Kenya Meat Commission has a history of closure of its operations the longest being 1993 to 2006. More than seven years after reopening, the commission is still dependent on the exchequer while it was expected to operate as a business by generating profits, sustain itself and contribute to the national economy. An article by VENTURES AFRICA quoted Kenya's Cabinet Secretary for Agriculture, Livestock and Fisheries, Felix Kosgey having revealed that the East African nation is on the move to re-enter the European Union (EU) meat market after it was banned. As a country, Kenya was banned from exporting meat to the EU and by extension KMC due to food safety concerns as it failed to create disease-free zones and meet hygiene conditions losing beef export quota of 400,000 tonnes per year .In the 1970s, EU market used to be one of Kenya's major export arena with about 66 percent of canned beef consumed in that market were exported by the Commission. Even as the Kenya's largest government owned abattoir finds itself in an uncertain state, the growth in the global population and the likely increase in purchasing power in many developing countries will result in increased meat consumption. The global population is also becoming increasingly urban which means that demand for ready to cook meals and ready to eat foods will increase including those for meat products. As population and the demand for meat increase we must plan for the growth of the meat business. The question we need to ask ourselves is whether Kenya as a country is prepared to tap into the growth in demand for meat through expanding its markets locally, globally or through diversifying or by specializing. Is the government owned Kenya Meat Commission (KMC) prepared in terms of policy, attainment of internationally acceptable hygiene standards, and accessibility of market information and pricing to be competitive in the market?

\section{Conceptual Frame Work}

Various in-puts such as raw materials, labor and equipment go into production process to generate finished goods for sale. Thus the output is a function of how these factors interact. The study sought to establish factors influencing the sustainability of Kenya Meat Commission. The researcher conceptualizes that the KMC can be sustainable if Challenges from Meat industry are adequately addressed. 


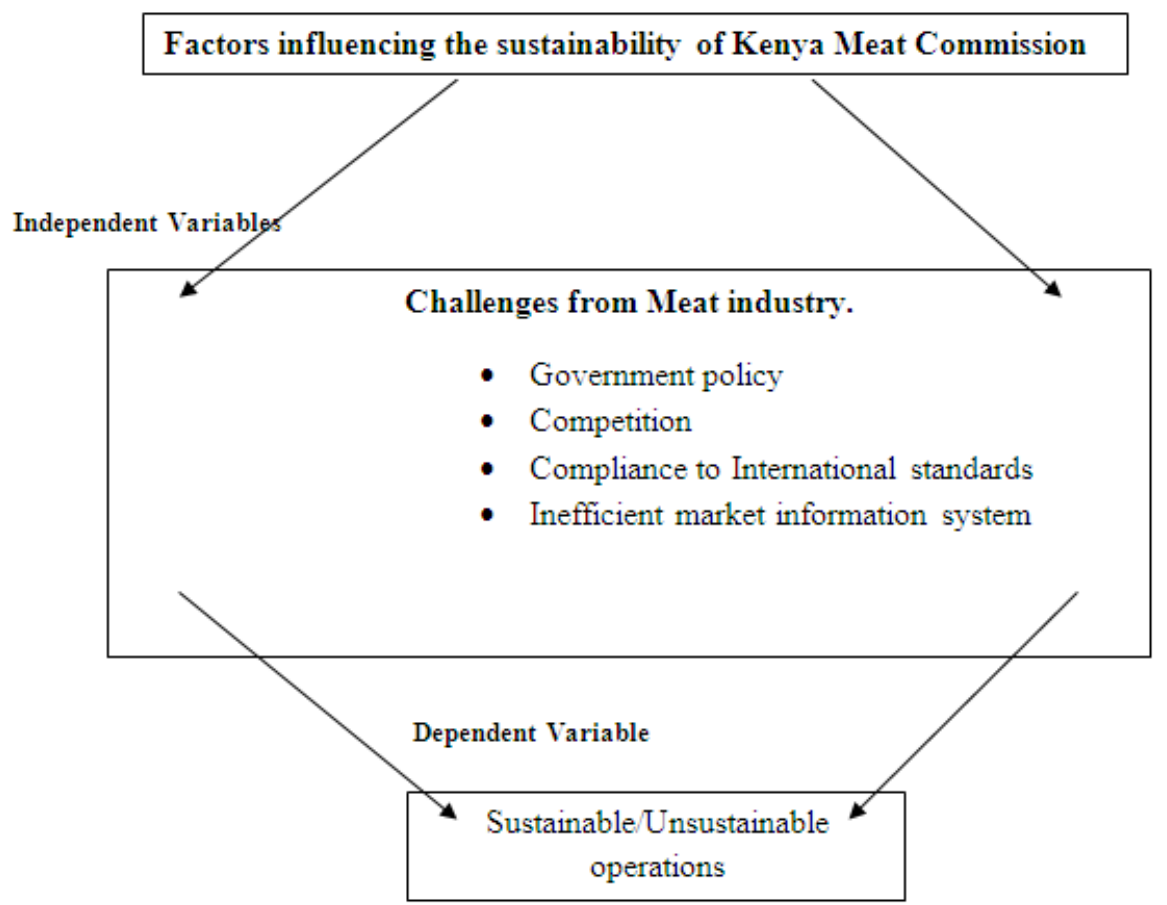

Figure 1.1 Conceptual framework

\section{Challenges from Meat industry}

One of the objectives of the government to re-open $\mathrm{KMC}$ was to provide a ready market for livestock producers. During times of drought the government mops up livestock which it then directs to KMC for slaughter. The effect on KMC operations is that quality of animals brought to its abattoirs is compromised, yet the Commission is expected to compete at the market place with other players. The commission's operational costs are also much higher than that of the competition. This because the commission buys livestock, slaughters and markets as opposed to other local slaughter houses that offer slaughtering services only. Kenya as a country has not been able to meet high standards set by foreign countries on livestock and livestock products. This limits the export market for KMC because the European Union market is inaccessible on account of not meeting their export standards. Lastly, Poor pricing mechanisms are mainly a result of poor market information systems that act as a key limiting factor to good market access. In conclusion the sustainability of KMC depends on addressing the above factors to improve on efficiency of operations as well as improve the operating and marketing environment.

\section{Research Methodology}

4.1 Research Design The investigator used a case study to collect data; hence the study is descriptive in nature. Kothari (2005) defines descriptive research as those studies that are concerned with specific predictions, with narration of facts and characteristics concerning individual, group or situations. This research is descriptive as it attempts investigate factors influencing the sustainability of Kenya Meat Commission, using both qualitative and quantitative methods of research.

4.2 Research Site The KMC Mombasa Branch is located at Mombasa County, Changamwe district along the Makupa Causeway where both the administrative offices and the processing plant are sited. The factory has an installed slaughter capacity of 250 cattle (large stock) and 500 (sheep/goats) small stock per day. Mombasa Plant was chosen for the study because of unique positioning in terms of proximity to the port of Mombasa for export market, challenges in communication networks and that the plant is yet to be International standard organization (ISO) certified.

4.3 Target Population The target population of the study was the employees of the KMC Mombasa branch. The total target population of the study was 50 people. 
Table1.1 Distribution of target Population

$\begin{array}{llll}\text { Category of Employee } & \text { Departmental population } & \text { Sample } & \begin{array}{l}\text { \%o of total target population } \\ \text { Production staff }\end{array} \\ \text { Livestock Procurement } & 23 & 20 & 86.9 \% \\ \text { Stocks } & 7 & 1 & 50.0 \% \\ \text { Legal } & 1 & 6 & 85.7 \% \\ \text { Sales \& Marketing } & 9 & 1 & 100 \% \\ \text { ICT \& Communications } & 1 & 6 & 66.6 \% \\ \text { Quality } & 3 & 1 & 100 \% \\ \text { Finance } & 4 & 3 & 100 \% \\ \text { Total } & 50 & 4 & 100 \% \\ & & 42 & 84.0 \%\end{array}$

4.4 Sample Design The study captured all members of staff from various departments, 23 of production, 2 supply chain and procurement , 7 stocks ,1 legal, 9 sales and marketing, 1 ICT , 3 Quality ,4 finance all within Mombasa. The population was therefore $50 \mathrm{KMC}$ employees and sample size of 42 .

4.5 Data Collection The main instrument for data collection was self-administered questionnaire. The investigator distributed the questionnaires to the targeted respondents and then collected after an agreed period of time of one week. The questionnaires consisted of both closed and open ended questions covering the challenges of procuring livestock and those of the meat industry. The questionnaires were used for ease of administration as the respondents could fill them in at their own time.

4.6 Data Analysis The data was analyzed through tallying the responses and calculating percentages against the total respondents. The information was then placed in descriptive statistics. The purpose of descriptive statistics according to Mugenda \& Mugenda (2003) is to enable meaningful distribution of scores by measures of central tendency. The findings were presented in tables and bar graphs to enhance ease of understanding.

\section{Results and Discussion}

The respondents demographic profile were analyzed under the following categories (job description, years of service in the commission and age). To gather information on factors influencing the sustainability of the Kenya meat commission Mombasa branch, the study gathered information from all cadres of the employees. Table 1.2 shows the distribution of respondents across departments.

Categories of employees
Legal
ICT
Procurement
Quality
Finance
Stock Unit
Sales \& Marketing
Production

$\begin{array}{lll}\begin{array}{l}\text { Table 1.2 Categories of Employees } \\ \text { Frequency }\end{array} & \begin{array}{l}\text { Cumulative percentage } \\ \text { Percentage }\end{array} & 2.4 \\ 1 & 2.4 & 4.8 \\ 1 & 2.4 & 7.2 \\ 1 & 2.4 & 14.3 \\ 3 & 7.1 & 23.8 \\ 4 & 9.5 & 38.1 \\ 6 & 14.3 & 52.4 \\ 6 & 14.3 & 100 \\ 20 & 47.6 & \end{array}$

The respondents aged below 30 years represented 55.0\% whereas another $40.0 \%$ were between $31-40$ years of age and $5.0 \%$ of the respondents were aged over 40years. Majority of the respondents were production staff aged below 30years of age. The length of service for majority of the respondents was over one year of service with $60.0 \%$ having worked for 1-3years and the remaining $40.0 \%$ worked over 3 years.

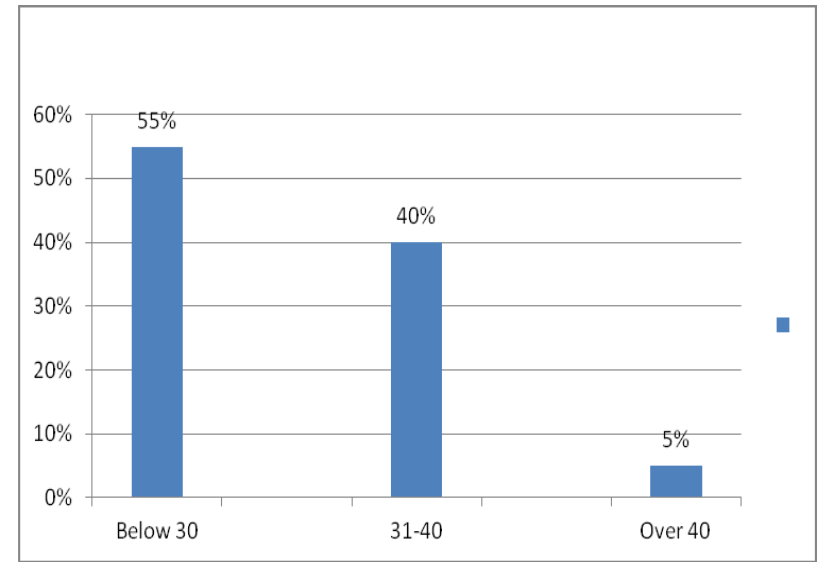

Figure 1.2: Age Distribution 
In management and supervisory category $15.0 \%$ of the respondents were males and $20.0 \%$ were females. In clerks and operators category $50.0 \%$ were males and $15 \%$ were females. In the management and supervisory category, the genders are fairly well balanced whereas in clerks and operators category there were more males than females. This is an indication of the mechanical nature of the slaughter process requiring masculinity. Challenges that emanate from the meat industry i.e. those from KMC external environment are Government policy, Competition, and inefficient market information system and compliance to international standards. The respondents rated the following factors that relate to Policy framework: Off-takes programs, Carcasses grading and Export of live animals.

\section{Rating}

Off-take programs

Carcasses grading

Export of live animals
Table 1.3 Policy and Legal Frame Work

$\begin{array}{lllll}\text { very strongly agreed } & \text { strongly agreed } & \text { agreed } & \text { barely agree } & \text { Disagree } \\ - & 20 \% & 10 \% & 60 \% & 10 \% \\ 75 \% & 20 \% & 5 \% & - & - \\ - & 35 \% & 45 \% & 20 \% & -\end{array}$

The legal assistant explains that Government policy intends Kenya Meat Commission to be the buyer of last resort during times of drought i.e. the government undertakes the off-takes programs to mop up livestock which are then directed to KMC for slaughter. KMC has no control over the quality of animals brought to its abattoirs for slaughter, yet the Commission is expected to compete at the market place with other players. KMC also operates under an ACT of parliament of 1950. One of the major areas of criticisms of the act is in the payment of suppliers based on the grading of carcasses i.e. on hot standard carcass weight (HSCW) being the most favorable method to process payments. The system is very unpopular with the suppliers and therefore open to abuse of bribery to attain higher grades that fetch more money. The sales officer adds that export of live animals to other African countries destabilizes the pricing regime of livestock in the Kenyan market. The Kenyan slaughter stock is inadequate especially during drought and it is the opinion of KMC legal department that the policy shouldn't encourage export of live animals as yet. Rather the policy should encourage achievement of the international standards to export value added products especially to EU Market.

The Quality assurance supervisor, legal officer, sales supervisor, ICT and communications officer were asked to comment on the following aspects of competition: Abattoirs in Mombasa,Meat suppliers from Nairobi, Imported Meat. The responses by the respondents were presented in table 1.4.

\section{Table 1.4 Competition}

$\begin{array}{llllll}\text { Rating } & \text { very strongly agreed } & \text { strongly agreed } & \text { agreed } & \text { barely agree } & \text { disagree } \\ \text { Mombasa Abattoirs } & 60 \% & 30 \% & 10 \% & - & - \\ \text { Nairobi Meat Suppliers } & 45 \% & 30 \% & 20 \% & 5 \% & - \\ \text { Imported meat } & - & 10 \% & 45 \% & 40 \% & 5 \%\end{array}$

The respondents confirm that KMC Mombasa competes for the local market with other meat suppliers. Competition against Mombasa abattoirs is skewed in favor of the latter because of lower operational costs. The Quality Assurance Officer explained that whereas KMC has to meet export slaughter standards, the other abattoirs that are licensed as local slaughter houses only need to comply with less stringent standards. For instance $\mathrm{KMC}$ has to generate huge quantities of steam to heat water to sterilize equipment for slaughter which is not mandatory for non-export abattoirs. This has cost implications and therefore the higher operational cost. The Livestock field officer also confirms that, whereas KMC have to source their own animals the other abattoirs in Mombasa do not, but offer a service to interested parties who bring their stock to the slaughter house. The latter can therefore afford concessions on hides, liver and tripes to bulk buyers, thus relegating KMC to selling their products to institutional customers like schools, hotels, colleges, universities, prisons and hospitals. It is important to note that most institutional customers' delays in payments are not uncommon constraining cash flow to the commission. The sales Officer adds that meat brought to Mombasa County from Nairobi, is mainly frozen products of specialized cuts. This is because the branch is lacking in meat freezing facilities and therefore cannot service a section of the available market. During times of scarcity some businessmen import meat from neighboring countries like Tanzania though not much to justify them as competition

On compliance to International standards, a question was posed to the Quality assurance supervisor, legal officer and sales supervisor to state their views on Non-compliance to international standards.

Table 1.5 Compliance to International standards.

$\begin{array}{llllll}\text { Rating } & \text { very strongly agreed } & \text { strongly agreed } & \text { agreed } & \text { barely agree } & \text { disagree } \\ \text { Attainment of ISO 22000 } & 40 \% & 30 \% & 20 \% & 10 \% & - \\ \text { Disease free zone } & 55 \% & 40 \% & 5 \% & - & - \\ \text { Organic feeding } & - & 30 \% & 35 \% & 30 \% & 5 \%\end{array}$

The respondents confirmed that Non-compliance to international standards namely Disease free zone (DFZ), International standard organization (ISO) certification as a food safety management system poses serious challenges in the branch being competitive. The ICT and communications officer, legal officer, Quality 
assurance supervisor and sales supervisor were asked to comment on the flow of information to the livestock industry in reference to the following aspects that promote trade: Producer\& consumer prices, International markets and Weather patterns.

$\begin{array}{lcclll} & \text { Table 1.6 Inefficient Market Information Systems } & \\ \text { Rating } & \text { very strongly agreed } & \text { strongly agreed } & \text { agreed } & \text { barely agree } & \text { Disagree } \\ \text { Producer \& consumer prices } & 20 \% & 35 \% & 40 \% & 5 \% & - \\ \text { International markets } & 45 \% & 30 \% & 15 \% & 5 \% & - \\ \text { Weather patterns } & 30 \% & 40 \% & 30 \% & - & -\end{array}$

The respondents strongly agreed that the livestock marketing information systems do not facilitate dissemination relevant information to the stakeholders. The ICT and communications officer explained that currently the market is dominated by cartels that influence the prices of both the raw material of the meat because of lack of a structured communication channels on Producer \& consumer prices .Communication on weather patterns is critical in advisory services to the livestock producers on drought mitigation measures.

\section{Discussion of results}

Based on the above, KMC Mombasa branch has challenges in accessing export markets due to inadequate standards, provision of timely \&relevant information, government policies and high cost of operations. These therefore, make the branch uncompetitive. The challenges can be surmounted through strategic planning, financial discipline, and support by the government by providing a conductive legal framework for business growth. The government policy and KMC Act should be evaluated and certain sections repealed to reflect the current operational realities of KMC. This will provide a level playing ground for all industry players. The government should strengthen livestock marketing information system by facilitating disseminations to both the producers and consumers. Given the importance of prices in determining livestock production and the farmer's earnings, there is need to institutionalize dissemination market information to all stake holders and establish linkages with other international markets. That way the livestock keeper and KMC as the buyer of Livestock will be less exposed to exploitation by middlemen. The Government requirements to Invest in creation of Disease free zones to facilitate raising a slaughter stock that meets the international standards. This will greatly open up markets in Europe for the commission. There is also need for the Government to strengthen training, supervision and regulation of service providers. This in turn would assure quality service delivery through enforcing a code of practice that will be acceptable to national and international standards at all stages of production and marketing.

\section{Summary Conclusion and Recommendation}

This chapter summarizes the interpretation of the data analysis in the previous chapter and it gives the conclusion and recommendations of the investigator based on the findings obtained. The data collection was based on the objectives and research question on the study. The broad objective of the study was to investigate factors influencing sustainability of Kenya meat Commission, a case study of Mombasa branch. The chapter summarizes the findings the key area of the research questionnaire namely the challenge of the meat industry and the impact on KMC operations. The chapter goes ahead to draw conclusions on this specific objective and gives recommendations to the sustainability of Kenya Meat Commission and areas for further research have also been identified and recommended. The response rate was fair at $84 \%$ of the targeted 50 respondents. The purpose of the study was to find out factors influencing sustainability of Kenya meat Commission Mombasa branch with specific reference to challenges of the meat industry. The study established that KMC challenges emanating from the meat industry are due to government policy, competition, inefficient market information systems and non-compliance to international standards. There is inadequacy in managing the above challenges that adversely affect the operations of Kenya Meat Commission. The management requires to formulate policy framework as a basis of addressing them and engaging the government to review the KMC Act to provide a more enabling environment for the meat industry to thrive. The government policy and KMC Act should be evaluated and certain sections repealed to reflect the current operational realities of KMC. This will provide a level playing ground for all industry players. The government should strengthen livestock marketing information system by facilitating disseminations to both the producers and consumers. Given the importance of prices in determining livestock production and the farmer's earnings, there is need to institutionalize dissemination market information to all stake holders and establish linkages with other international markets. That way the livestock keeper and KMC as the buyer of Livestock will be less exposed to exploitation by middlemen. The Government to Invest in creation of Disease free zones to facilitate raising a slaughter stock that meets the international standards. This will greatly open up markets in Europe for the commission. There is also need for the Government to strengthen training, supervision and regulation of service providers. This in turn would assure quality service delivery through enforcing a code of practice that will be acceptable to national and international standards at all stages of production and marketing. Further research should be carried 
out on the following:The effectiveness of the meat grading system as basis for paying suppliers. The challenges of a centralized system of procurement and supplier payments at Athi River with a view of making Mombasa branch semi-autonomous. Diversification of KMC's range of products to meet the ever growing demand for meat and meat products.

\section{References}

[1]. Aklilu, J. \& Wekesa M. (2001). Impact assessment report of the emergency interventions to support livestock during the 19992001 drought in Kenya. A Consultancy Report for the KenyaFood Security Steering Group (KFSSG), Acacia consultants. Nairobi.

[2]. Antonio, R. \& Ahmed, S. (2010). Livestock planning, challenges and strategies for livestock development in IFAD.

[3]. Barton, D. \& Morton J. (2001). Livestock marketing and drought mitigation in northern Kenya. NRI, Chatham, Kent, England.

[4]. Behnke, R.H. (1983). Production rationales: The commercialization of subsistence pastoralism. Nomadic Peoples, 14: 3-34.

[5]. Behnke, R.H. (1987). Cattle accumulation and the commercialization of the traditional livestock industry in Botswana. Agricultural Systems, 24: 1-29

[6]. Bekure, S. \& Chabari F. (1991). An economic analysis of Maasai livestock production

[7]. Coppock, D.L. (1994). Borana household economy: Development intervention concepts.

[8]. Coppock, D.L. (Ed.), The Borana plateau of southern Ethiopia: Synthesis of pastoral research, development and change, 19801991. ILCA, Addis Ababa,Ethiopia.

[9]. Coppock, D.L. (1992). Observation on traditional logic of pastoral livestock marking in southern Ethiopia

[10]. Danny Muller (1988). The academy of management volume 31 No. 2.

[11]. Danny Muller (2002). Strategic management for voluntary non-profit organization.

[12]. Evangelou, P. (1984). Livestock development in Kenya's Maasailand: Pastoralist transition to a market economy.

[13]. Farhad A. (2003). Business and economics.

[14]. Holtzman, J. \& Kulibab, N. (1995). Livestock marketing in pastoral Africa: Policies to increase competitiveness, efficiency and flexibility.

[15]. Herr, R. (1992). Pastoralism in Africa: Paths to the future. A review of Mennonite experience with African pastoralists

[16]. Hussein A. (2010) a study of Livestock Trade in the Kenyan, Somali and Ethiopian Borderlands Theories of strategic planning

[17]. Hendrickson, D., Armon T. \& Mearns R. (1998). Conflict andvulnerability to famine: livestock raiding in Turkana, Kenya. Issue Paper No. 8, IIED, London.

[18]. Herbeson, J.W. (1992). Post-drought adjustments among horn of Africa pastoralists: Policy and institution building dimensions Johnson and Scholes (1993), Strategic Planning

[19]. Jurgen, C., Schmidt S. \& Martyn L. (1997). Understanding the Theory and Process of Strategy Development.

[20]. KMC (2007). Kenya Meat Commission Service Charter

[21]. Kothari (2004), Research Methodology, methods and techniques

[22]. Mugenda \& Mugenda (2003) Research Methods, quantitative and qualitative approaches.

[23]. Nishiguchi, T. (1994) Strategic Industrial Sourcing. Oxford University press, ISBN 0-19-507109-3. New York

[24]. Nyariki, D.M. \& Ngugi R.K. (2001). Contribution of livestock to food security in agro pastoral systems

[25]. Payne, W. (1976). Systems of beef production in developing countries.

[26]. Perrier, G. \& Gray, C., (1992).Proceedings of the International Rangeland Symposium on Development of Range Science.

[27]. Pratt, C. (2001). Traditional early warning systems and coping strategies for drought among pastoral communities of north-east Kenya.

[28]. Pratt, D.J. and M.D. Gwynne (1997). Range management and ecology in East Africa.

[29]. Smith G.(2000). Beef cattle production in developing countries. Centre for Tropical Veterinary Medicine

[30]. Sandford, S. (1983). Management of pastoral development in the Third World. Turner Mcnabb Consulting, Ll. www.tutor 2u.net (2009, (http://libguides.usc.edu/writingguide- Last Updated: Feb 22, 2013URL)

[31]. Cheryl Conner, Challenges every business faces (www.linkedin.com/in/cherylsnappconner) VENTURES AFRICAKenya to Reenter EU Meat Market, (info@ventures-africa.com). 